University of Nebraska - Lincoln DigitalCommons@University of Nebraska - Lincoln

To Improve the Academy

Professional and Organizational Development

Network in Higher Education

1990

\title{
Strategies for Monitoring and Improving Seminars: An Application in a Course on Managing Computer Integrated Manufacturing
}

Paul Mangiameli

Seetharama Narasimhan

Glenn R. Erickson

Follow this and additional works at: http://digitalcommons.unl.edu/podimproveacad

Part of the Higher Education Administration Commons

Mangiameli, Paul; Narasimhan, Seetharama; and Erickson, Glenn R., "Strategies for Monitoring and Improving Seminars: An Application in a Course on Managing Computer Integrated Manufacturing" (1990). To Improve the Academy. 200. http://digitalcommons.unl.edu/podimproveacad/200

This Article is brought to you for free and open access by the Professional and Organizational Development Network in Higher Education at DigitalCommons@University of Nebraska - Lincoln. It has been accepted for inclusion in To Improve the Academy by an authorized administrator of DigitalCommons@University of Nebraska - Lincoln. 


\section{Strategies for Monitoring}

and Improving Seminars: An Application in a Course on Managing Computer Integrated Manufacturing

\section{Paul Mangiameli}

\section{Seetharama Narasimhan}

\section{Glenn R. Erickson}

The University of Rhode Island

Teachers are nearly always curious about how their courses are going. Professors wonder if their students are learning, if the students are being appropriately challenged, and if they are liking the course and the instructor's teaching style. That curiosity and concern is especially intense for new courses in relatively uncharted areas, particularily if the expectation is that the course will become a regular part of the curriculum. Under such circumstances it is important to monitor the course continuously, to make adjustments as needed, and to collect information about overall success at the end. In this paper we describe our collaborative effort to monitor, adjust, and assess a new interdisciplinary seminar created and taught by Mangiameli. We do not think that our procedures or experience are unique or exceptional, but hope that a relatively detailed account of our particular application will be interesting and useful to other practitioners. 


\section{The Course}

The management of computer integrated manufacturing (CIM) systems is a new subject that involves the perspectives of engineering, business, computers, and information systems. It is an important area, inherently difficult to teach, with no established pedagogical tradition (Dilts, Mangiameli, Narasimhan, \& Mosier, 1989). The Management of Computer Integrated Manufacturing Systems was a three-credit course which met one morning per week throughout a 15-week semester. Four MBA and two Industrial and Manufacturing Engineering graduate students were enrolled. The course was designed to teach basic terms, skills, concepts, and issues likely to be encountered in managing a CIM system. Topics were examined from both a technical and managerial perspective to facilitate the development of a comprehensive approach to managing this critically important technological and organizational system.

Because of the level, ability, and background of the students, the interdisciplinary and nonstandard course content, and the small class size, the course was offered as a seminar. Each student prepared for and led the class discussion twice during the semester. There were also weekly text and journal reading assignments, collaboratively written consulting reports, and individual term papers. There were no examinations.

\section{Course Monitoring and Feedback Techniques}

For this course, Mangiameli was particularily interested in exploring questions such as:

1. How well are the classes being managed each week by the student discussion leaders, and should the instructor be more or less involved in helping to plan or manage those discussions?

2. Are students finding the focus and coverage of the readings and discussions of each topic appropriate for the course?

3. Is each topic being treated so that students will be able to apply what they are learning to "real world" problems?

4. Is the class format engaging students and promoting their learning?

5. Are there unanticipated problems which need to be handled?

Mangiameli got together with Narasimhan, a faculty colleague, and Erickson, the instructional development director, at an organizational meeting of would-be "classroom researchers." We decided that a combination of brief questionnaires and periodic student interviews would be a reasonable way to gather information regarding these questions. 
Questionnaires were developed collaboratively with the university's Instructional Development Program (IDP), a center for consulting with faculty about their teaching. The questionnaires included the Weekly Class Reaction Survey and the Mid-semester and Final Course Evaluations (see Appendix). The weekly survey included several items soliciting reactions to the conduct of the week's discussion, an overall class rating item, separate items for rating the week's text and journal readings, and room to note questions or unresolved issues which needed to be pursued. Those surveys were completed anonymously each week by the students and the instructor. The IDP typed up the comments and summarized the data for the instructor and discussion leader each week.

There were several reasons for using a weekly questionnaire. We wanted to be able to refine the teaching of each topic in subsequent offerings of the course, so we did not want students' reactions to the course as a whole to overwhelm their recollections of how well each topic had been treated. The student discussion leaders needed to get timely feedback about their performance. The weekly survey also made it possible to clear up any misunderstanding about a particular topic at the beginning of the next class. Finally, frequent surveys made it easier to discern and respond to any trends such as inappropriate depth of coverage, unsuitable readings, or poorly managed discussions.

The Mid-semester and Final Course Evaluations collected more global reactions to the course. They asked students to assess their learning and to provide overall ratings and comments about the course format, the readings, and such. In addition, students were asked how much time they were investing and for advice about the professor's role in the course. The results of these evaluations were summarized by the IDP but were shared only with the instructor.

Katz and Henry (1988) imply that questionnaires and occasional comments from students do not provide adequate depth either for understanding how well students are learning or for guiding the improvement of teaching practices. We decided, therefore, to take their implicit advice and supplement the questionnaire data with regular student interviews. Each week through the mid-semester Narasimhan conducted individual interviews with the week's discussion leader and one other randomly selected student. The identity of the second student was not disclosed to the instructor. The interviews were brief, more conversational than structured, and centered upon the students' sense of what they were learning and their reactions to the conduct of the class. A summary of those conversations was given to the instructor each week. If questions or issues 
were raised that needed further clarification, they were followed up in the next week's interviews.

Overall, then, the instructor received student feedback each week from the class reaction surveys and the student interviews. He got more general reactions to the course from a mid-semester and end-of-course evaluation by students. Students received ratings from their peers and the instructor each time they acted as discussion leaders.

\section{Using the Feedback}

Although student responses to the course content and format were generally positive from the beginning, the interviews and the questionnaire data did alert the instructor to several issues during the semester that did need attention. The most important of these concerned the performance of the discussion leaders, the quality of the assigned readings, and student fears about their ability to apply the course material to the "real" world.

The discussion leaders for the first few weeks indicated during the interviews that they were having difficulty in deciding how to focus discussion and felt the need for more direction. Although they were spending more than ten hours preparing for their discussions, their efforts were too scattered. That lack of focus was reflected in the weekly ratings and written comments by their peers as well. In response, the instructor asked each leader to prepare an advance list of possible discussion questions and to review them with him before class. A revised set of questions was then distributed during class. Improvement was dramatic, immediate, and documented by peer ratings and comments in the interviews. Students indicated, moreover, that if they all had the questions in advance, they could also be better prepared discussion participants. The questions were thereafter distributed two days before class meetings. Finally, students decided that they could do a better job as discussion leader in their second round if they could review the ratings of their colleagues' performances. In spite of the instructor's initial reluctance to risk embarrassing anyone, the students were adamant and unanimous in their desire to share those ratings - perhaps because none had received nasty reactions during the first round. Consequently, the IDP's summary of the previous week's ratings were distributed each week along with the discussion questions.

The assigned readings were another problem area. Students complained in the interviews and on the weekly questionnaires that the readings were too extensive, often redundant, and sometimes too technical. The instructor began to cull the assignments of the most technical and 
repetitious readings after the third week. Student ratings and comments reflected their increased satisfaction. There were still negative comments about occasional research papers assigned during the semester; those comments will be taken into consideration in making up the reading list for future students. Obviously, those which received positive comments or generated lively and productive discussions are likely to be retained.

The textbook did not fare so well. It generated little discussion and consistently received lower ratings than the other readings. It will not be used in this course again. The clear message from the student ratings was that the readings should not be "textbookish," highly technical, or redundant. Apparently, a few well-selected readings on each topic at the level of Harvard Business Review, California Management Review, CIM Review, or IEEE Transactions on Engineering Management articles are best suited for this type of seminar.

Another issue might have been missed had it not been for the interviews. Students worried that they would not be able to apply what they were learning to industrial settings. Because repeated assurances by the instructor were not enough to bolster their confidence, a class meeting with a local manufacturing company was arranged for late in the semester. The company's Director of Engineering was contemplating the adoption of a Computer Aided Design (CAD, a major component of CIM) system for his department and agreed to have the class serve as his consulting team. After the meeting, the class wrote a preliminary report that he found so useful and persuasive that adoption was postponed until the engineering department received further training. The students found the experience very reinforcing and several commented on it in the end-ofcourse evaluation.

While concerns about preparing for discussions, the readings, and the utility of the course content in the "real world" were probably the most salient, students and the instructor had additional reservations and questions as well. One of the weekly topics was an apparent misfit and will be dropped in the future. The students also suggested some rearranging of topics, and that was done. Finally, the instructor worried about how active a role he should take in the conduct of the class discussions and how much he needed to consult with discussion leaders in advance of class. Students were polled on those questions on the mid-semester evaluation; they thought he was about as active as he should be, but two wanted more consultation in advance of class.

Most of the news from the mid-semester and end-of-course evaluations was reassuring rather than demanding of action. All of the students 
thought they were learning "a great deal" or "a fair amount"; they were overwhelmingly favorable about the course format; and their overall ratings of the course were very positive.

\section{Discussion}

Planning and teaching new courses is always a challenge, all the more so when they are advanced, interdisciplinary courses. We believe that such courses go best if instructors and students get lots of feedback as they go. We have reported here on our use of a combination of interviews and brief questionnaires as sources of information to help the instructor and students in an interdisciplinary seminar monitor and fine tune the course and their performance. The overall result was a new course which went exceptionally well after some potentially serious issues were resolved.

We think that the combination of student interviews and a mix of weekly and occasional questionnaires could be readily used to improve courses in a wide variety of disciplines. Developing questionnaires is relatively easy if the instructor has a reasonably clear idea of what he or she wants to know, and administering them takes little class time. We think that responses will be more forthright and useful if student anonymity can be assured, so having an instructional development service, a departmental secretary, or student assistant to type up comments, tally item responses, and summarize the results is an advantage.

Arranging and conducting student interviews need not be complicated either. Finding a colleague who knows something about your subject matter, is willing to sit in on an occasional class in order to establish a common frame of reference with students, and will devote an hour or two a week for a few weeks to interview students and meet with you to discuss the results is probably the ideal. Short of that, having the interviews done by a colleague from another department or a student would probably work well enough. No particular training is necessary, but the Katz and Henry (1988) book has some useful suggestions. More important is for the instructor and interviewer to come to agreement on any issues which ought to be raised with students routinely or at certain points in the term.

The weekly questionnaires, the occasional surveys, and the student interviews each contributed significant and useful information. We believe that using any one of them alone would probably be worthwhile. But each of them missed some particularly useful information, so we recommend trying out the set - especially given the relative ease and low cost of using them all. 


\section{References}

Dilts, D.M., Mangiameli, P.M., Narasimhan, S.L., \& Mosier, C.T. (1989, November). Teaching computer integrated manufacturing. Proceedings of the Decision Sciences Institute (pp. 147-148). New Orleans, La.

Katz, J., \& Henry, H. (1988). Turning professors into teachers. New York: MacMillan. 


\section{Appendix \\ Weekly Class Reaction Survey}

Please read each of the first seven items and choose the response which best matches your reactions to today's class. Your choices are:

A) No improvement needed (Terrific! Keep up the good work.)

B) Little improvement needed (Maybe a ragged edge or two, but nothing to lose sleep over.)

C) Improvement needed (Not awful, but merits some attention.)

D) Considerable improvement needed (This is a problem; please try to work on it.)

Today in class...

A B C D 1. The scope of presentation and discussion was limited to a manageable number of important ideas or questions.

A B C D 2. It was clear why the material presented and discussed was important - e.g., how it might be used in this course or elsewhere.

A B C D 3. The key ideas or questions related to the topic were highlighted.

A B C D 4. Plenty of good examples for clarifying abstract or difficult material were presented.

A B C D 5. There was enough variety to keep me reasonably interested and alert.

A B C D 6. The main points which we were expected to take away from the class were summarized clearly.

A B C D 7. The day's topic was clearly integrated with the various topics treated in the course.

Please take another couple of minutes to answer the following questions. 
8. What is your overall rating of today's class?

excellent

good

satisfactory

fair

poor

9. What made you rate today's class as high as you did?

10. What kept you from rating today's class higher?

11. Please indicate your overall ratings of this week's text and journal readings by circling the appropriate number on each scale below.

a) text readings: $\begin{array}{lllllllllll}1 & 2 & 3 & 4 & 5 & 6 & 7 & 8 & 9 & 10\end{array}$

$$
\text { awful okay excellent }
$$

b) journal readings: $\begin{array}{llllllllll}1 & 2 & 3 & 4 & 5 & 6 & 7 & 8 & 9 & 10\end{array}$

$$
\text { awful okay excellent }
$$

Comments:

12. Please note any questions or unresolved issues which you think we ought to take time to pursue further. 


\section{Mid-semester and Final Course Evaluation}

Please take a few minutes to think back on this course over the first half of the semester. Your thoughtful reactions and suggestions will be very much appreciated.

1. How much do you think you are learning so far in this course?

a. a great deal

b. a fair amount

c. very little

d. virtually nothing

2. How would you compare the general approach to conducting this course (student presentations each week, readings, no exams) to a more typical format (lectures, readings, exams)?

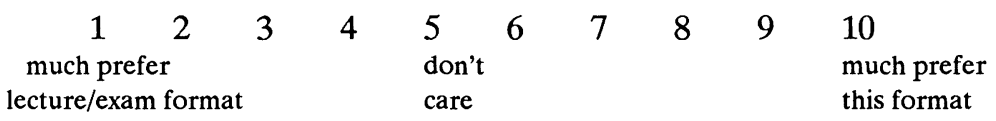

3. On average, about how much time have you spent preparing for this class each week? (Please write in your estimates below.)

a. in weeks that you were not presenting

b. in week(s) when you presented

4. What is your overall rating of the text readings so far?

$\begin{array}{llllllllll}1 & 2 & 3 & 4 & \begin{array}{l}5 \\ \text { awful }\end{array} & 6 & 7 & 8 & 9 & \begin{array}{l}10 \\ \text { excellent }\end{array}\end{array}$

5. What is your overall rating of other assigned readings so far?

$\begin{array}{llllllllll}1 & 2 & 3 & 4 & \begin{array}{l}5 \\ \text { awful }\end{array} & 6 & 7 & 8 & 9 & \begin{array}{l}10 \\ \text { excellent }\end{array}\end{array}$

6. How active a role should the professor take in the conduct of the class?

-a. more active than he has so far

b. about as active as he has been

c. less active than he has so far 
7. How much consultation between professor and presenter in advance of class is needed?

a. more than there has been so far

b. about as much as there has been

c. less than there has been

8. So far, what is your overall rating of this course?

$\begin{array}{llllllllll}1 & 2 & 3 & 4 & \begin{array}{l}5 \\ \text { awful }\end{array} & 6 & 7 & 8 & 9 & \begin{array}{l}10 \\ \text { excellent }\end{array}\end{array}$

9. What have you liked most about the course?

10. What have you liked least about the course?

11. Comments or suggestions:

Thank You 